\title{
Between Mythical and Post-industrial Wilderness
}

\author{
Pavel Klvač \\ Department of Environmental Studies, Faculty of Social Studies, Masaryk University Brno, Joštova 10, 60200 Brno
}

Received $4^{\text {th }}$ of July 2012; accepted $6^{\text {th }}$ of November 2012

\section{MEZI DIVOČINOU MYTICKOU A POSTINDUSTRIÁLNÍ}

ABSTRAKT O divočině se dnes často diskutuje jako o opozitu kulturní krajiny, či krajiny vůbec. Hranice mezi přírodou a kulturou (krajinou a divočinou) však nepředstavuje, jak by se mohlo zdát, cosi esenciálního nebo objektivního, spíše se jedná o kulturně vytvářenou kategorii. Př́roda, tradičně chápaná jako svébytně biologicky založený jev - určitá „danost“ - se v tomto smyslu jeví sociálně konstruovanou realitou, vymezovanou pomocí obrazů a rétorických prostředků sociálními aktéry. Ve vnímání divočiny lze identifikovat dva důležité aspekty. Bývá vnímána jako nebezpečná a nezkrotná a zároveň i neobdělávaná pustina. Postindustriální krajina ostrou hranici mezi civilizací a přírodou stírá, nese výrazné poselství obou světů - kulturního i př́rodního. Tato nová divočina má svoji relevanci v kulturním zvýznamňování i ochraně prírody.

KLÍČOVÁ SLOVA sociální konstrukce prŕrody; krajina; kulturní krajina; divočina; pustina; postindustriální divočina

ABSTRACT The term "wilderness" is nowadays often discussed as distinct from the cultural landscape or landscape in general. Nevertheless, this distinction is not objective, but it is rather a cultural construct. In this sense, Nature, traditionally perceived as independent phenomenon, is a socially constructed reality. In this paper it is argued that at least two important aspects in the perception of wilderness can be identified. The first is that wilderness can be represented as something cruel or ungovernable; the second one identifies wilderness as an uncultivated area. The evolution of wilderness perception is described. The concept of post-industrial landscape is presented as a conjunction of the previously characterised approaches, which unifies culture and wilderness. Examples of cultural and biological importance in post-industrial landscape are presented.

KEY WORDS social construction of nature (naturework); landscape; cultural landscape; wilderness; wasteland; post-industrial wilderness

When talking about landscape, wilderness is often discussed today (e.g. Vondruš 2000, Dejmal 2001, Librová 2001, Míchal 2001, Hájek 2002). Wilderness is conceptualized in contrast to the cultural landscape, or to landscape in general. This interpretation is a case of the variation on the classic theme of the antinomy of nature and culture (Lévi-Strauss 1962). The border between nature and culture (in other words, between a wilderness and a landscape) does not mean, however, that these concepts are something essential or objective. Rather, ideas about landscape and wilderness represent culturally created categories. "If we were able to project landscapes and wilderness of all cultures on a world map, we would soon find out that the areas considered wilderness have never been wilderness in the real sense of the word. These were almost always the areas in which, more or less, 'the cultural maps' overlapped. One society recognised the place as landscape, the other one as wilderness, for one it meant the home and for the other one a danger" (Hájek 2002, 16).

Nature, traditionally interpreted as an originally biological phenomenon - a certain given fact - (similar to race or gender), appears to be a socially constructed reality defined by the conceptions and rhetorical means of social participants. Fine $(1998,2001)$ uses the word "naturework" to describe the way in which individuals qualify nature with the help of cultural patterns and define their relation to nature. According to Fine, nature is worked in the way that social participants (individually or in groups) look for and find a certain sense in their relation to the environment and this sense then express. 


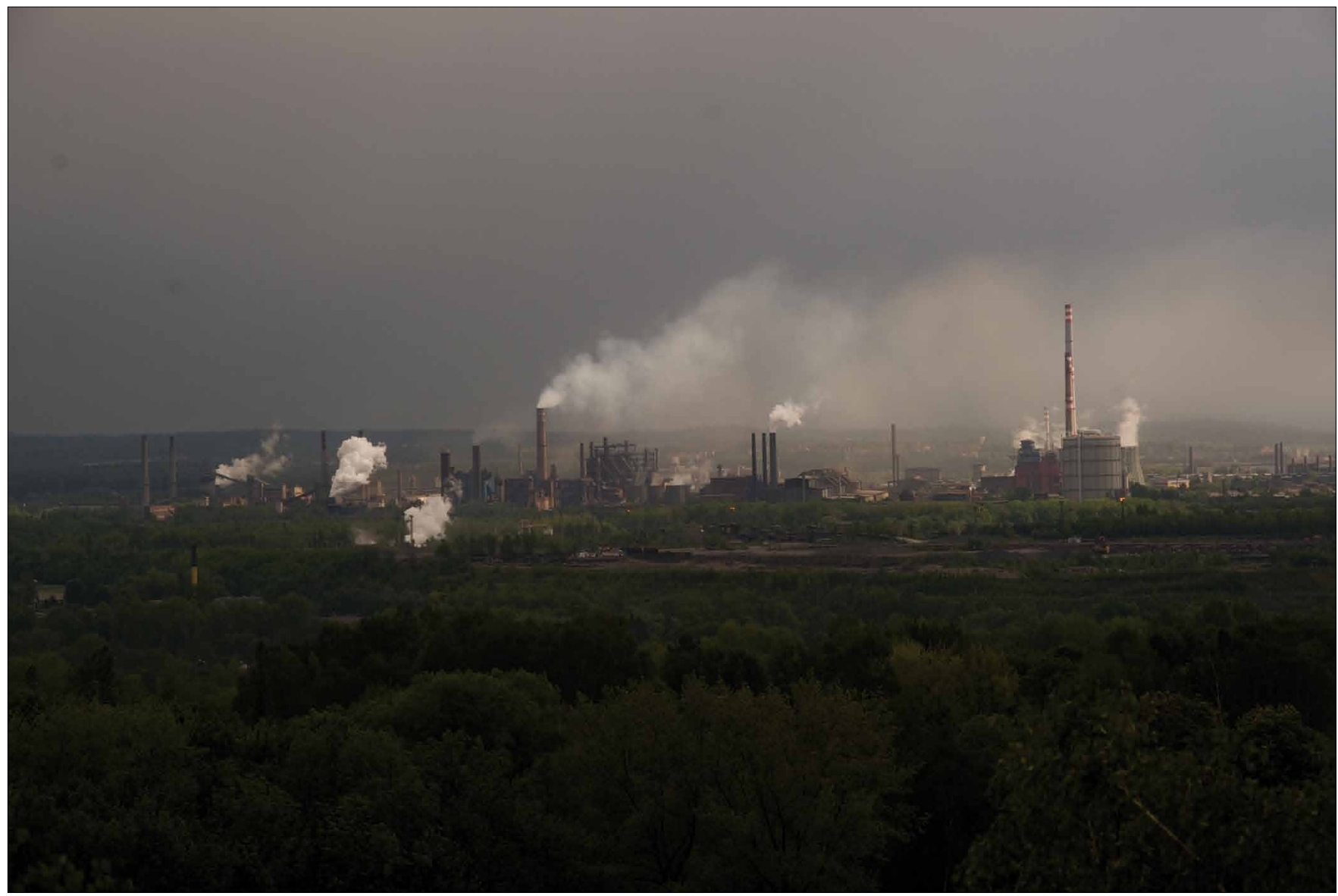

Fig. 1. Ostrava - The ArcelorMittal Ostrava a.s. steelworks, view from the Ema slagheap. Photo: Lumír Mlčák, 2010.

Through naturework people attribute certain meanings to the environment and in a way locate themselves in the surrounding world. Natural objects become transformed: objects turn into symbols. Culture is derived from nature by gradually created meanings (Fine 2001, 31). Nature is made meaningful by its cultural mediation. Meanings of nature are derived from socially predefined patterns. Nature as a concept is based on human learning, on cultural events and on social organisation. "Nature", "wilderness" and "the environment" are socially constructed categories of objects (Eder 1996).

\section{MYTHICAL ORIGINS OF THE “WILDERNESS” CONCEPT}

For Eliade (1994) the archaic human is religious - Homo religious. This human being longs for a world free from tension caused by relativity and from anxiety stemming from disorientation. S/he requires a sign that helps him/her to find a guiding principle. The qualitative differentiation of the guiding principle from homogeneous space continuity is represented by hierophany (breach of sanctity). The revelation of a holy space enables one to find a guiding principle, enables one to orient oneself in chaotic homogeneity, and enables one to establish "the world" and live in reality.
This event can be reached by different rituals. One of them is, for example, a beast of prey-hunt. A sanctuary is set up where the beast is beaten. A desire to live in a holy space equals to a desire to live in objective reality. This desire equals the effort not to allow oneself to be paralysed by the endless relativity of a very subjective experience. This equals the desire to live in a real and effective world not in a mere illusion. A defining feature of traditional cultures is that they perceive their inhabited territory (the holy space) in a sharp contrast to the surrounding unknown indefinite space. The inhabited territory represents "our world" - the Cosmos. The unknown space then stands for a kind of "the other world" - "Chaos", which is a strange chaotic space inhabited by demons or "aliens". These "others" are often likened to demons and souls of the dead. An agricultural settlement itself represented a world pattern in traditional cultures. In the languages of ancient Indo-Europeans the word vis meant "a village" and also the universe, entirety, the all. Even as late as the beginning of the $14^{\text {th }}$ century inhabitants of the village Montaillou in the Pyrenees believed that hell begins somewhere behind the backyard of their village where souls of the dead wander, chased by demons. In northern mythology the human world was represented by an enclosed farm outside of which the world of evil giants and monsters dwelled (Budil 2001, 32-33). In ancient and medieval geographical maps the known part of world was always 


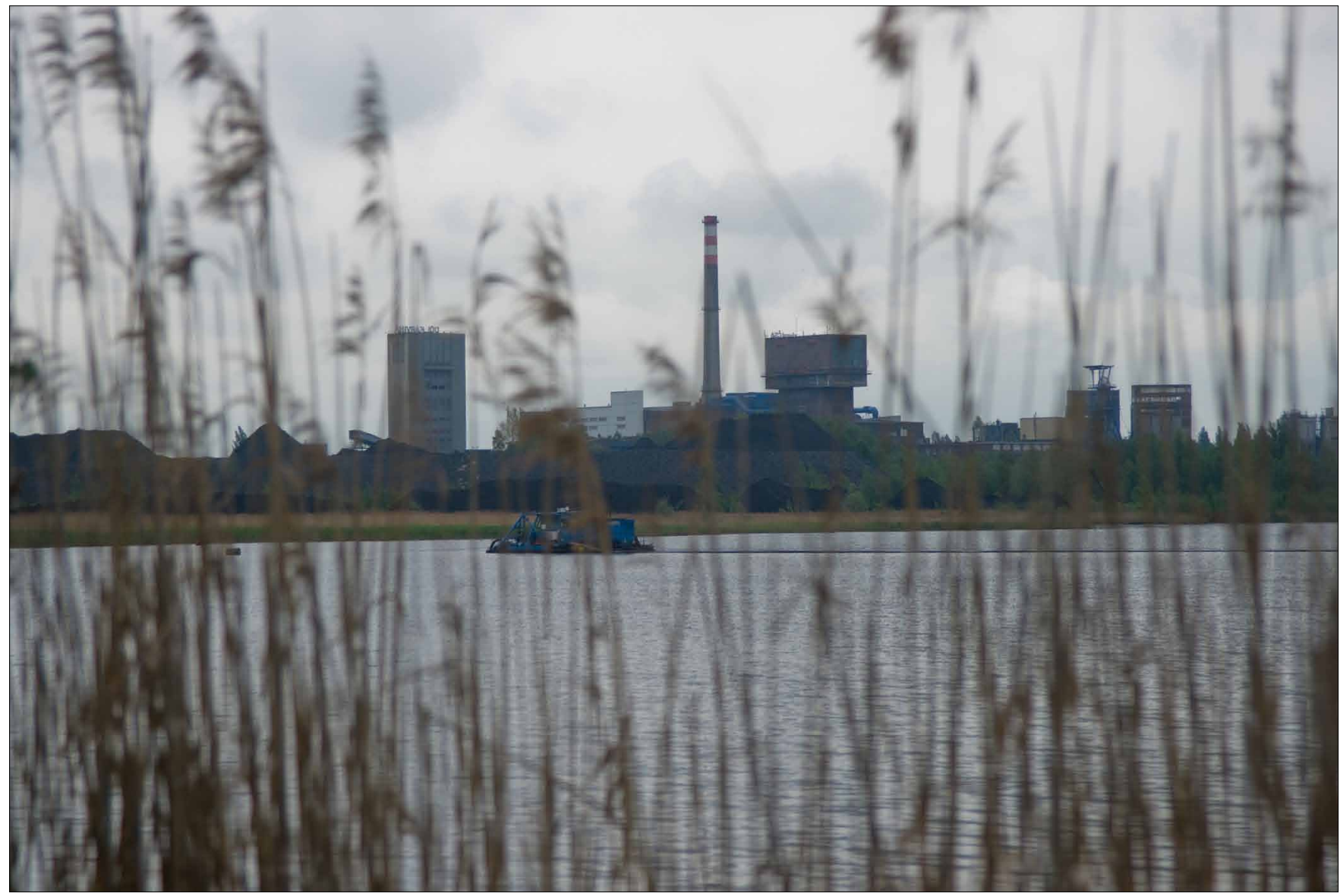

Fig. 2. The Czechoslovak Army Mine (currently the ČSA Mine) in Karviná with a tailing pond in the background. Photo: Lumír Mlčák, 2010.

placed in the middle. Its borders were then surrounded by animals, creatures and demonic figures.

On one hand there was "the cosmos" and on the other "chaos" - an unknown and uninhabited territory. All that does not represent "our World" does not even exist from the archaic society's point of view. When a human settles and occupies a particular territory, s/he symbolically turns it into the cosmos through ritual repetition of cosmogony. To settle in a place means to sanctify it. By cultivating a wasteland a human repeats the act of gods who brought order to chaos and so introduced a structure, order, shapes and norms. A farmer's work is then at the same time a symbolic colonisation of space - its "cosmosation".

In all these cultures one can find symbolism of the hub of the world. The hub is the place where levels break, where space becomes holy and a real par excellence. To "open" a place upwards, to connect it with heaven, to become a channel from one type of being to another one, is precisely how such a place is sanctified. One of the images representing such a place, which connects heaven and earth, is a mountain. In mountains the hub of the world is often found. (Temples are thus often copies of a cosmic mountain.) The mountain is the place nearest to heaven. One can reach heaven from its top. "Our world" is in this sense "a raised place".

Symbolism of the earth represents the opposite. The earth is connected with the underworld, which is often symbolised by the pre-shape modality of a cosmic substance of water chaos; by the world of the death; by everything that precedes and follows a life. At the same, "the water chaos" preceding the creation time symbolises a descent back into a shapeless state through death, a return to an elementary modality of existence. From a certain point of view it is possible to identify the underworld with the left and unknown territory that surrounds the inhabited place. The underworld, which our "cosmos" is based on, corresponds to the "chaos" that reaches its borders (Eliade 1994, 31).

\section{WILDERNESS AS CHAOS AND WASTELAND}

The English wildness means lack of restraint, spontaneity, freedom. "The word wild recalls a fox running in the woods, disappearing in the bush, sometimes in sight, sometimes out of sight. Closely at first glance, it is wild. Then further in history and deeper in the forest, it is wyld. Through the Old Norwegian villr and the Old Germanic wilthijaz it disappears in the vague Proto-Germanic gweltijos, which means silent, wild and perhaps even wald (wood). Back it comes stealthily with possible reference to will (will, energy), to the Latin silva (wood, ungovernable) and to the Indo-European root ghwer as the 


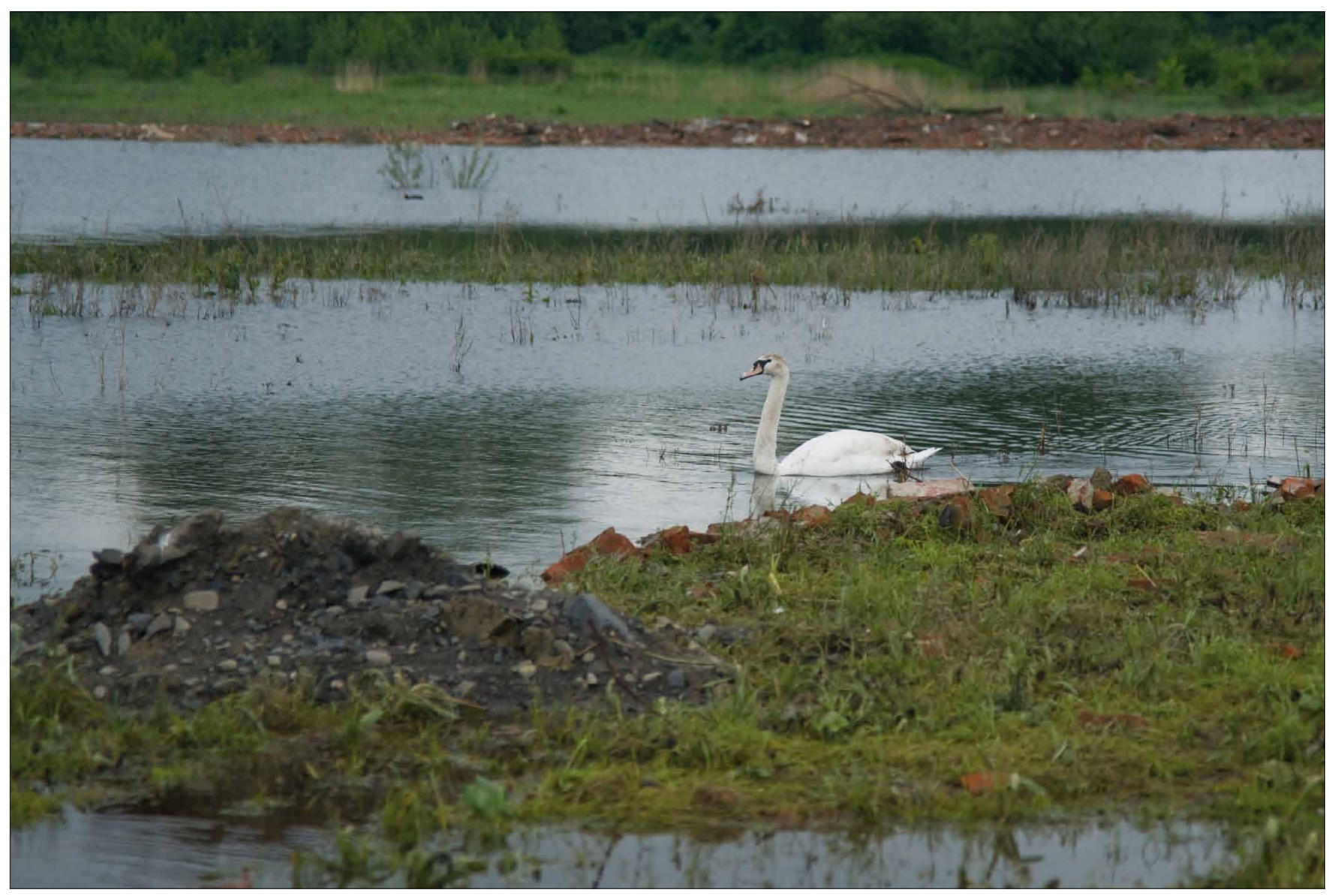

Fig. 3. A mute swan (Cygnus olor) on the ČSA Mine tailing pond in Karviná. Photo: Lumír Mlčák, 2010.

base for the Latin ferus (feral, fierce)..." (Snyder 1999, 17). The Oxford English Dictionary gives following meanings (according to Snyder 1999, 17-18): "about animals - untamed, indomitable, stubborn; about plants - uncultivated; about land - uninhabited, uncultivated; about edible crops - growing and producing unaffected by cultivation; about societies - uncivilised, primitive, refusing an established government; about individuals - wild, stubborn, licentious, debauched, amoral; about manners - violent, destructive, cruel, disobedient; about behaviour - unrefined, free, spontaneous."

According to the encyclopaedia Ottưv slovník naučný, wilderness is "a land covered in tall grass, bushes and woods; which has not been cultivated for ages; where the human foot has hardly ever stepped in; where new and more lush vegetation grows out of the dead matter. If forest trees outnumber bushes there, the wilderness is called a primeval forest" (Ottův slovník naučný 1997, 671).

In the perception of wilderness one can identify at least two very important levels that are closely connected.

On the first level wilderness represents something "ungovernable", "untamed", "cruel" - therefore chaotic and dangerous. Whatever the size of the home space is - a culture, land, village, house or ego - a human has always the need to live in an arranged world, in the cosmos. The border between our (comprehensible) world and the other world does not exist in itself. The idea such a border must be guarded all the time. All ambiguity undermining a purposeful arrangement has to be eradicated; the created order has to be fixed (Douglas 1994). Such a border, which organises our world, which is then wellarranged for us to orient ourselves to and thus made bearable, is as well a line that splits up "our world" (the civilised world) and chaos, which is represented by wild nature. Wilderness is perceived as a contradiction (a rival) to an order carefully created by culture. The existence of wilderness itself is a source of anxiety and unease. Eliade $(1994,36)$ says: "It is very probable that the original purpose of defence systems around inhabited places and villages was magical defence. These defence systems - ditches, labyrinths, ramparts etc. - were rather adapted to prevent an attack of demons and souls of the dead than an attack of people."

On the second level, wilderness represents an uncultivated wasteland. Cultivated land was for first farmers a space gained with great difficulty at the expense of the wilderness. This battle fought in the Middle Ages is described by Gherubini: "Indirect proof of a growth in population in Europe of the $10^{\text {th }}$ and $11^{\text {th }}$ century can be found in data showing an increase in the number of town inhabitants and in the number of towns; data of reduction in forest areas, marshland and wasteland; 
data of increases in cultivated land acreage (...). Local names of many municipalities all over the continent: 'New Towns', 'New Villages' (...) serve as proof of this heroic battle between peasants and almighty nature (...). The most significant stage of an even more difficult fight with water, sea and swamps was dikebuilding in Flanders and Dutch Zeeland. However, the English peasants also fought a successful battle with the sea when they drained salty marshland; even the Bretons and the people from Poitou, as well as the Italian peasants, drained marshes, built embankments and fought constantly against emerging new waters in the whole lowland of the river Pad and in many other inland places. (...) The dependence of agriculture on the caprices of nature and the permanent threat of poverty, which involves difficulties with the long-range transport of agricultural products, explain agriculturalists' constant anxiety about the crop" (in Le Goff 1999, 103-106).

Both of the above-described levels blend together in Czech mythology, recorded in The Old Czech Legends: "Almost all the land rested untouched by a hook plough. All - lowlands, plains and valleys, was more deserted and wilder. (...) There were plenty of bogs and swamp land in the fields and woods; plenty of treacherous swamps enlivened by the screech of water birds; plenty of black and eerily silent moorlands on which ancient trees looked down (...) The human footprint was rare here (...) There humanity came and cultivated the wasteland; made the land productive through hard work and sanctified the land through sweat and blood (...) Hard was the journey through deep forest, hard was the journey through meadows and marshes full of reeds, sedge and large moss clumps and diverse undergrowth. (...) It was a time when the women with large heads and crazy eyes cast their wild cries on people; when beautiful wood nymphs with wreaths upon golden hair wore revealing snow-white robes. The inhabitants were afraid also of wicked wood nymphs who might lull them to sleep and poke out their eyes; of lost souls appearing in bluish flames in moors and marshes; and they were scared when they passed lakes or forest pools where, in the shadow of ancient trees, water sprites lurked (...) Hunters told about fights with bears and buffalo or about wild unshaven invisible men who would make a man go round in circles and then lead him into the wasteland or swamps, so that many hunters had never come back from the forest" (Jirásek 1999, 5-11).

\section{CHANGES IN PERCEPTION OF WILDERNESS}

A feeling of ontological safety was traditionally created in confrontation with nature that was perceived as wilderness (dangerous and empty), which was the main cause of previous existential anxieties for humans. Connected with the successful adaptation of civilisation was the fact that "the development of science and technology extends the range of possible manipulation with hitherto 'natural' phenomena, and in this way enhance the dominance of culture" (Bauman 1996, 138). Modern knowledge, and its concomitant excessive manipulation of the environment, gradually became a main source of

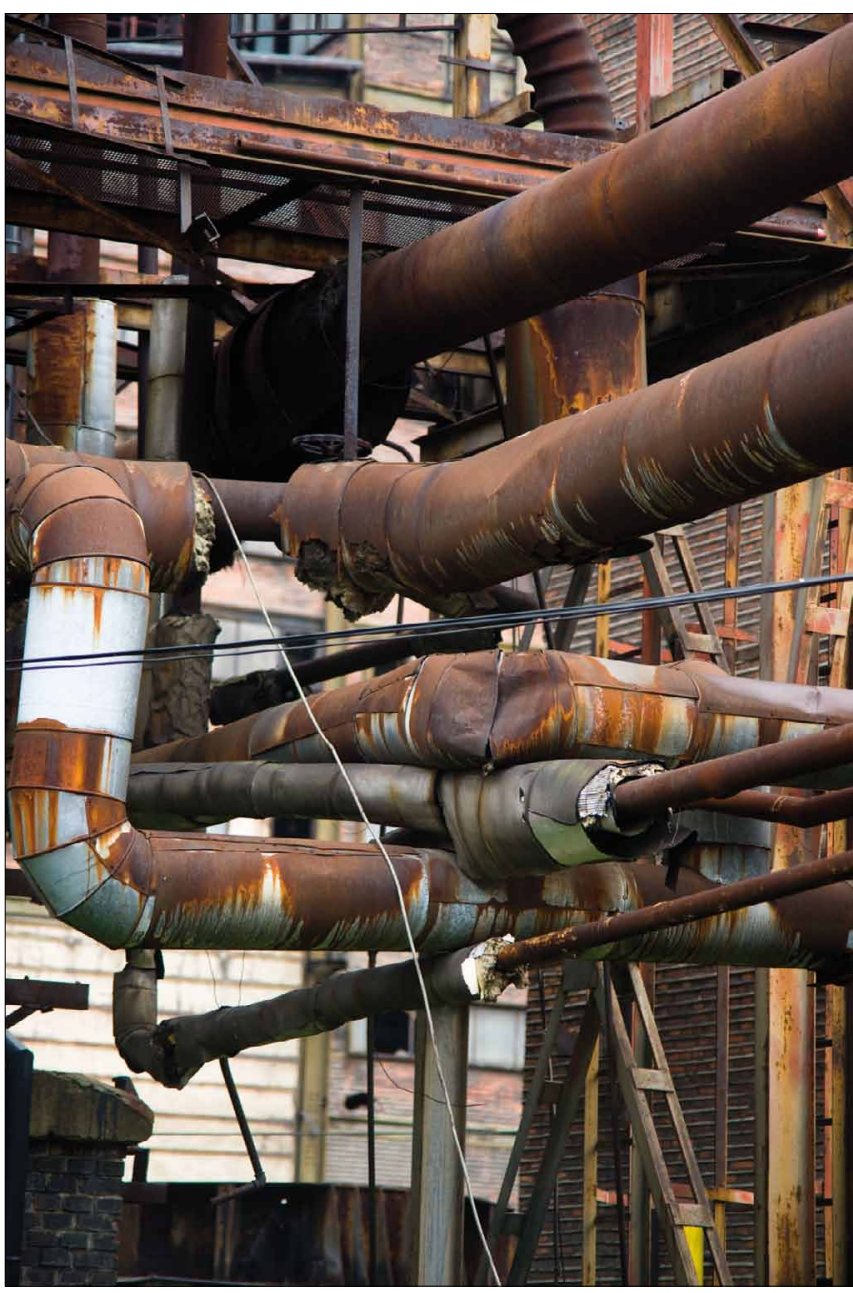

Fig. 4. Post-industrial I - National cultural monument - the blast furnaces of Lower Vítkovice. Photo: Lumír Mlčák, 2010.

modern risks (Beck 1992). The existence of wild nature began to be to a large extent dependent on the will of humanity.

Igor Míchal, in his article "The Historico-cultural Base of Attitudes Towards Landscape: Wilderness - Cultivated Land - City (Metamorphosis of Relationships)", puts forward the hypothesis that the "original values of wilderness were undoubtedly negative. Positive values could become associated with wilderness only when it had lost something of its ominousness and could be perceived from the safe civilised oasis of cities" (Míchal 2001, 15). One can assume that the attitude of archaic cultures towards wilderness was rather more ambivalent than schematic, as Míchal suggests. Yet only romanticism associates substantially positive meanings with nature (e.g. Librová 1988). However, the birth of organised preservation movements in support of the wilderness is of a later date.

The first attempts to stop the destructive wave of mass slaughter of wild animals were made in South Africa. "On the $12^{\text {th }}$ of July in 1822, Governor Lord Charles Somerset initiated a modification of historic importance. It defined the first modern plan for nature preservation, which became a pattern for similar projects all over the world. Governor Somerset's modification 


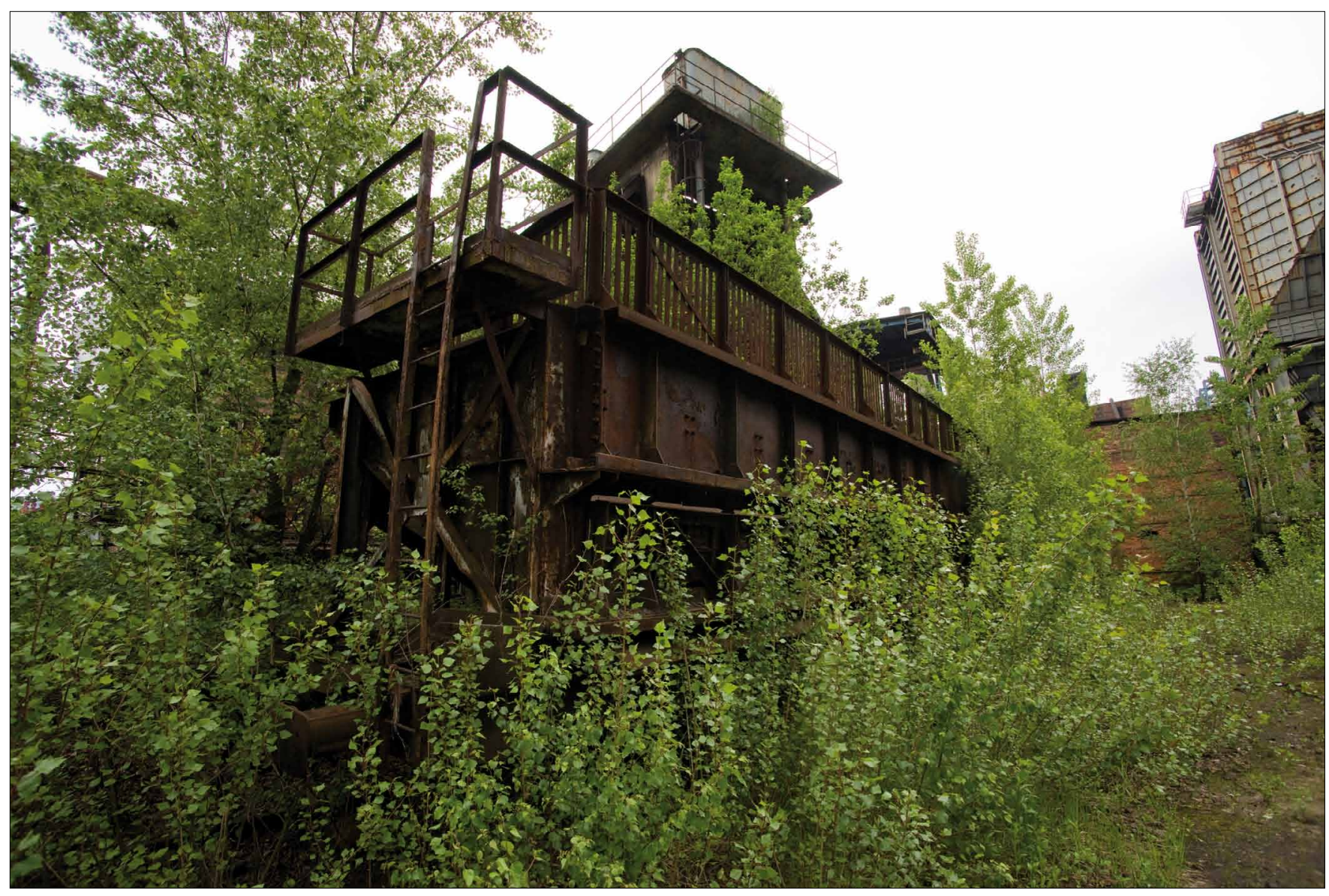

Fig. 5. The progress of ecological succession among the blast furnaces of Lower Vítkovice. Photo: Lumír Mlčák, 2010.

was an example of how to make a summary of complex regulations and resulted in a list on which endangered species could be later added and the unthreatened crossed out. If only Europeans had adopted such regulations sooner in the other territories they colonised. Actually, even in those British colonies where liberal officers were strong enough to resist the opinions of settlers and aborigines, there was only a half-hearted approach to use similar regulations. For example, in India elephants started to be preserved only in 1873" (Johnson 1998, 227).

On the North American continent, systematic efforts to preserve the wilderness began to be developed as an answer to brutal ways of nature appropriation resulting from the tide of colonists. "The contrast of the beauty of virgin nature and its disastrous destruction, as well as adventurous romance, gave rise to the cult of wilderness in American culture and touched the consciousness of the most sensitive (Yellowstone National Park was legalised in 1878)", writes Míchal $(2001,22)$.

One would look for wilderness, in the sense of nature untouched by humans ("natural" ecosystems), with a great difficulty in the Czech Republic (Sádlo - Storch 1999; Primack et al. 2001). Here the scientific interpretation of wilderness is of a qualitatively different rank. A wilderness symbolically colonised by a sign system of science does not represent a "threatening", "dangerous", or "enemy" force or fear-raising mystery - mysterium tremendum (Otto 1998) - but a relatively independently developing ecosystem - "close-to-nature" or "natural" ecosystems (Míchal 1992).

In spite of expert scientific definitions, the term "wilderness" is today frequently mentioned in all spheres of the everyday language. The current boom of various magazines and manuals of the kind - how to survive as a tourist in a "wilderness" - proves the increasing popularity of romantic trips, excursions or expeditions by organised or individual tourists seeking domestic and foreign "wilderness" experience. In Czech conditions this trend erpresents a similar phenomenon described earlier by American sociologists in the USA - e.g., Brooks (2001).

\section{THE POST-INDUSTRIAL LANDSCAPE AS PENETRATION OF CULTURE AND WILDERNESS}

The landscape of the post-industrial era (Bell 1973) removes here and there the sharp border between civilisation and nature and carries a significant message of both the cultural and natural worlds. Abandoned quarries, sandpits, waste dumps, slag heaps, and unused settling pits come to be somewhere on the midpoint. Industrial areas left to their fate return into 


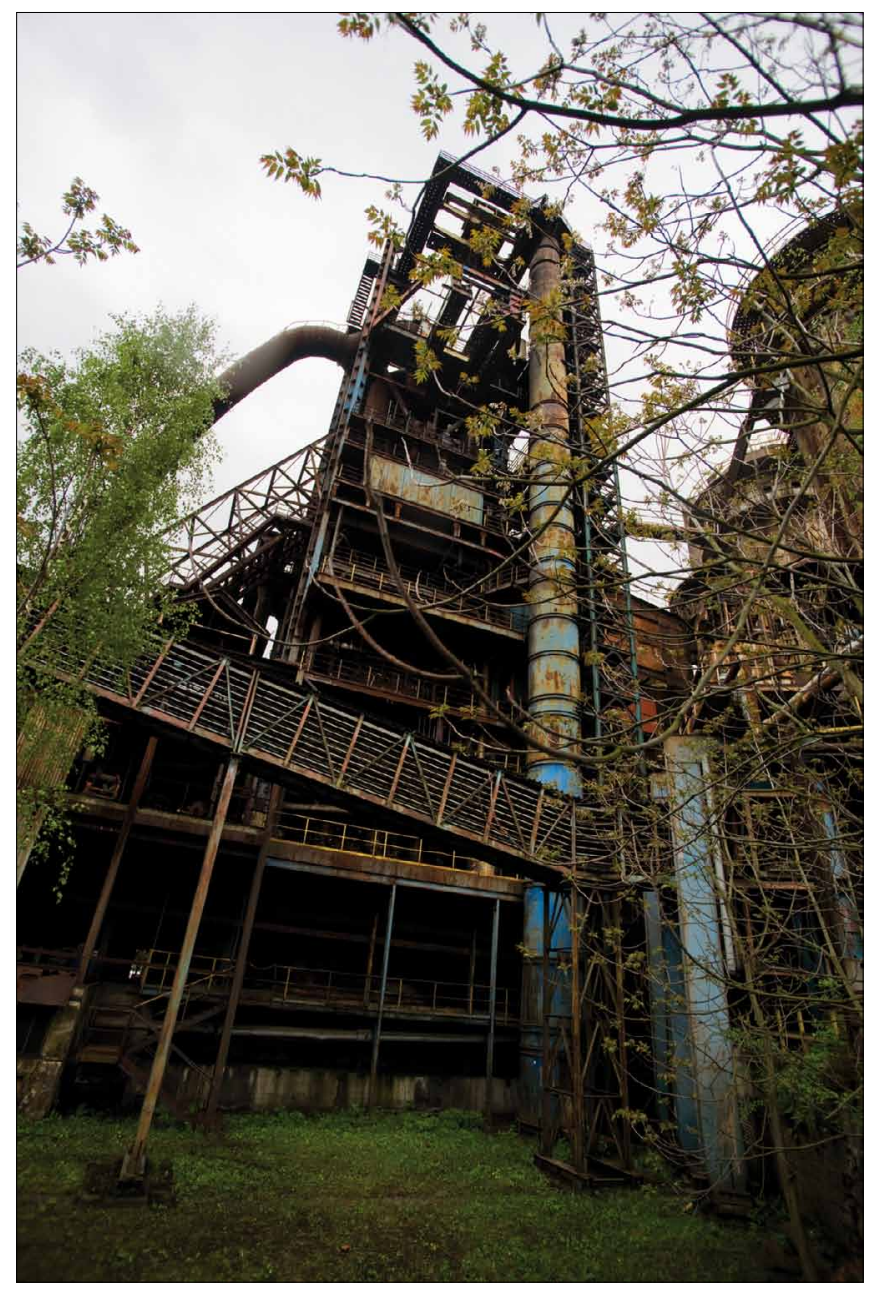

Fig. 6. Post-industrial II - National cultural monument - the blast furnaces of Lower Vítkovice. Photo: Lumír Mlčák, 2010.

wild nature's clutches: "Rusty steal frames are covered under creeping plants so one can hardly distinguish between metal and chlorophyll. Floral piercing. (...) Further a kind of interconnection of metal, people and gradually winning plants. A certain conviction that these particular places reveal the deep and mundane essence of the world. Here it is obvious how close human pipes and their insulation are to a moss cover and birch roots" (Cílek 2002, 75-76).

Václav Cílek introduces a new artistic category - the "found installation". When visiting the abandoned area of the Koněv ironworks (steelworks) near Kladno, the surroundings become a gallery to him (as with a factory for Vladimír Boudník), which challenges and excites the imagination to contemplation: "There one realises with relief that nature is not only a magnificent temple of nobility, but also mundane and unscrupulous. There the bottomless materialism of the first capitalists and the social architects is finally penetrated by the awful pragmatism of natural phenomena. The installation removes the difference between J. V. Stalin and the lower fungus to allow several active graphic works of Vladimír Boudnik, several paragraphs of Bohumil Hrabal to emerge from this monstrous

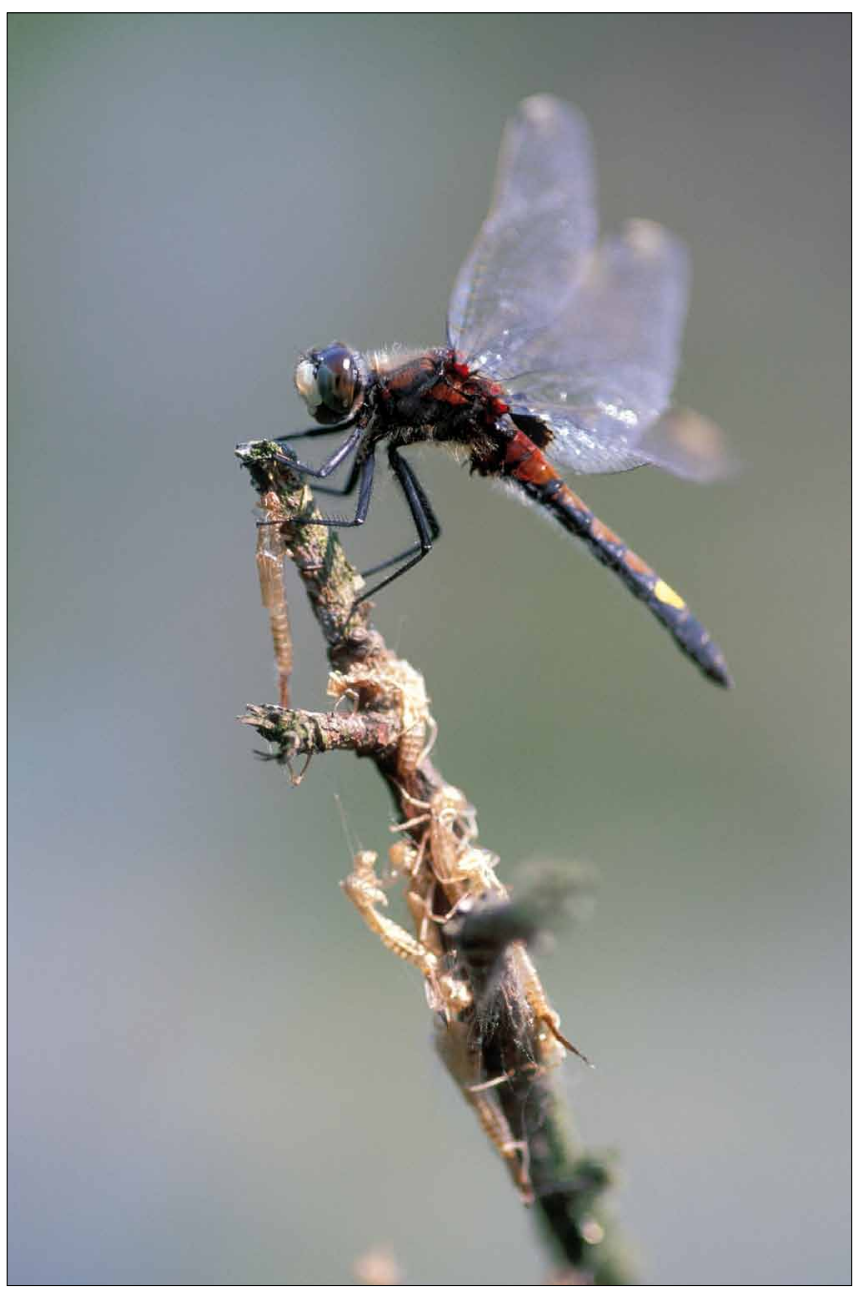

Fig. 7. Large white-faced darter (Leucorrhinia pectoralis) - one of the centers of the range of this European protected species in the Czech Republic is located in the industrial landscape of the Karvinsko region. Sites where mine subsidence have occurred are very important refugia for this species. Photo: Dan Bárta.

mycelium and imprint itself into several suicidal tendencies of Wittgenstein's brothers. It fills us with reverential awe and then with so much aesthetic, disgusting cognition of one shared part of the world that we had to escape" (Cílek 2002, 76).

The cultural dimension of areas from the industrial era left by civilisation can be a topic for a discussion about aesthetics; however, the location is visible at first glance - dilapidated buildings, growing rusty pipes, geometrical chaos. This evokes our "instinct of linearity" (Cílek 2001, 33) to a reclamation effort. On the other hand such localities represent potential habitats for many valuable botanical and zoological species.

One can have an ambivalent view of nature in an industrial city such as Ostrava, as is found in the narrative book Príroda Ostravy by V. Koutecká $(2001,9)$. The author herself says: "The mushroom-like growth of the city caused destruction of the balance of nature on its most territory and in its neighbourhoods. Surprisingly, right in Ostrava there are, at present, localities whose natural value has not been noticeably lowered by human activity." The book presents the traditional point of view 
of an industrial landscape and concentrates on examples of flora and fauna in nature preserves, whose existence in this region is a rather remarkable peculiarity. Nevertheless, it is this particular post-industrial landscape that allows space for the existence of a possibly much more interesting and valuable habitats of a "wilderness" character, whose emergence one can consider to be a side products of human work.

With a more detailed look at the industrial landscape of the Ostrava and Karviná region one can find several significant features of an industrial landscape (Sádlo - Storch 1999), such as a noticeable reduction in the physical presence of humans in the landscape but of human influence upon it; the sharp division of landscape into parts totally controlled by humans and parts free from human influence; the growth of wood acreage and an ongoing reduction in forest species diversity; and increasing disturbances in the landscape.

Simultaneously, valuable extreme habitats with many rare species come to existence through human industrial activities. For example, the occurrence of rare or endangered taxa (Dolný $2001 \mathrm{a}, \mathrm{b}$ ) of dragonflies was proved in the older localities where industrial sedimentation basins are separate from the typical subsidence basins and canals. This was exceptionally significant in case of Libellula fulva which was considered extinct, exterminated or missing for a period of at least 50 years until it was found in the Mokroš sedimentation basin (Dolný 2002; Hanel - Zelený 2000). Other groups of rare or specially protected species, whose occurrence can be unique within the whole Czech Republic, are dependent on the secondary wetlands and water ecosystems in industrial areas. This is true for both plant (Stalmachová - Špačková 2001) and animal species (Ďuriš - Horká 2001; Dolný - Duriš 2001), such as Pontastacus leptodactylus, Anodonta cygnea and the European Beaver (Castor fiber). These examples from the Karviná surroundings are matched by data of rare entomological fauna found on slag heaps in Ostrava (Dolný 2000) and in quarries in central Moravia (Konvička, Beneš 2001); of amphibians in discharge chutes of North Bohemia (Vojar 2000); and of orchids on slag heaps in Great Britain (Morris et al. 2003).

Post-industrial wilderness as an example of "new wilderness" deserves our attention. Because this idea of wilderness has yet to be absorbed in both our physical (natural) and mental (in art e.g. Hepher et al. 2003) landscapes we should not make precipitous judgements, which we may be unconsciously lured into by ancient deep mythical connections.

\section{REFERENCES}

Bauman, Zygmunt (1996): Myslet sociologicky. Praha: Slon.

Beck, Ulrich (1992): Risk Society: Towards a New Modernity. London: Sage.

Bell, Daniel (1973): The Coming of Post-Industrial Society. New York: Basic Books.

Brooks, David (2000): Bobos In Paradise: The New Upper Class and How They Got There. New York: Simon \& Schuster.

Budil, Ivo, T. (2001): Za obzor Západu. Praha: Triton.

Cílek, Václav (2001): Geologické základy české krajiny. In: Dejmal, Ivan, ed., Tvář naši země - krajina domova, Lomnice nad Popelkou: Studio JB, 27-34.
Cílek, Václav (2002): Kladno - nalezená instalace. Analogon, 36, 74-76.

Dejmal, Ivan (2001): Kulturní krajina dnes - zpustnutí nebo návrat divočiny. In: Němec, Jan, ed., Krajinotvorné programy. Př́ibram: Centrum pro otázky ochrany prírody a krajiny Př́bram, 81-85.

Dolný, Aleš (2000): Budou na odvalech chráněná území přírody? Živa, 4, $173-176$.

Dolný, Aleš (2001a): Neobvyklý výskyt vážky jasnoskvrné (Leucorrhinia pectoralis, Odonata: Libellulidae) v důlní poklesové kotlině v Karviné. In: Vážky 2001: Sborník referátů IV. celostátního semináře odonatologů v NP Šumava. Vlašim: ZO ČSOP Vlašim, 124-130.

Dolný, Aleš (2001b): Využití vážek k indikaci stavu prostředí v hornické krajině. Acta Facultatis Rerum Naturalium, Universitas Ostraviensis 200, Biologica-Ekologica, 8, 100-107.

Dolný, Aleš (2002): Libellula fulva Müller, 1764 (Odonata) na důlním odkališti v Karviné. Časopis Slezského muzea Opava, 51, 51-57.

Dolný, Aleš - Ďuriš, Zdeněk (2001): Výskyt ohrožených bezobratlých na důlních odkalištích v Karviné. Živa, 6, 268-270.

Douglas, Mary (2000): Purity and Danger: An Analysis of the Concepts of Pollution and Taboo. London: Routledge.

Ďuriš, Zdeněk - Horká, Ivona (2001): K výskytu raka bahenního Pontastacus (=Astacus) leptodactylus Eschscholtz na Karvinsku. Časopis Slezského muzea Opava, 50, 78-84.

Eder, Klaus (1996): The Social Construction of Nature. London: Sage Publications.

Eliade, Mircea (1994): Posvátné a profání. Praha: Česká křestłanská akademie. Hájek, Pavel (2002): Obecné dějiny intolerance. In: Hájek, Pavel, ed., Krajina zevnitřr. Praha: Nakladatelství Malá Skála, 14-24.

Hanel, Lubomír - Zelený, Jiří (2000): Vážky (Odonata): Výzkum a ochrana. Vlašim: Český svaz ochránců prrírody.

Hepher, David - Hughes, Patrick - Gibbons, John - Keane, John, - Burutynsky, Edward - Lewis, Tim (2003): Postindustriální krajina - The Postindustrial Landscape. Katalog k výstavě. České muzeum výtvarných umění v Praze ve spolupráci s galerií Flowers v Londýně.

Jirásek, Alois (1999): Staré pověsti české. Praha: Ottovo nakladatelství.

Johnson, Paul (1998): Zrození moderní doby: Devatenácté století. Praha: Academia.

Konvička, Martin - Beneš, Jiří (2001): Stepní motýli a ekologický význam lomů. Živa, 4, 172-174.

Koutecká, Věra (2001): Příroda Ostravy. Ostrava: Statutární město Ostrava.

Le Goff, Jacques, ed. (1999): Středověký člověk a jeho svět. Praha: Vyšehrad.

Lévi-Strauss, Claude (1962): The Savage Mind. London: Weidenfeld and Nicolson.

Librová, Hana (2001): Kulturní krajina potřebuje náš smír s divočinou. In: Dejmal, Ivan, ed., Tvář naší země - krajina domova, Lomnice nad Popelkou: Studio JB, 129-133.

Librová, Hana (1988): Láska ke krajině? Brno: Blok.

Fine, Gary Alan (1998): Morel Tales: The Culture of Mushrooming. Cambridge (Massachusetts) - London: Harvard University Press.

Fine, Gary Alan (2001): Jak se dělá př́roda a ochočuje divočina: Problém „vysbírávání“ lesů v houbařské kultuře. Biograf - časopis nejen pro biografickou sociologii, 24, 29-56.

Míchal, Igor (1992): Ekologická stabilita. Brno: ZO ČSOP Veronica.

Míchal, Igor (2001): Kulturně historická východiska postojů ke krajině: Divočina - obdělaná zem - město. In: Dejmal, Ivan, ed., Tvář naší země - krajina domova, Lomnice nad Popelkou: Studio JB, 13-25.

Morris, Dick - Freeland, Joanna, R. - Hinchliffe, Steve - Smith, Sandy, eds. (2003): Changing Environments. Chichester: John Wiley \& Sons

Otto, Rudolf (1998): Posvátno. Praha: Vyšehrad.

Ottův slovník naučný (1997): heslo „Divočina“. Díl sedmý. Praha: Paseka a Argo, 671.

Primack, Richard, B. - Kindlmann, Pavel - Jersáková, Jana (2001): Biologické principy ochrany prírody. Praha: Portál.

Sádlo, Jiř́i - Storch, David (1999): Biotopy České republiky. Praha: Vesmír.

Snyder, Gary (1999): Praxe divočiny. Praha: Mata.

Vojnar, Jiří (2000): Sukcese obojživelníků na výsypkách po povrchové těžbě hnědého uhlí. Živa, 1, 41-43.

Vondruš, Dan (2000): Více divočiny nebo trvalé udržitelnosti? In: Hájek, Tomáš - Jech, Karel, eds., Téma pro 21. století - Kulturní krajina (aneb proč ji chránit?). Praha: Ministerstvo životního prostředí, 90-94. 


\section{AUTHOR}

Klvač, Pavel (13. 9. 1974, Vyškov), a sociologist who works at the Department of Environmental Studies in the Faculty of Social Studies at Masaryk University in Brno. He deals with methodological approaches to environmental research in the areas of the humanities, environmental sociology, rural and landscape issues.
Contakt: Mgr. Pavel Klvač, Department of Environmental Studies, Faculty of Social Studies, Masaryk University Brno, Joštova 10, 60200 Brno, e-mail: klvac@fss.muni.cz 
